\title{
Research on Aristotelian Virtue Education
}

\author{
Zhilin Yang \\ Department of Philosophy, School of Humanities and Social \\ Science \\ Dalian University of Technology \\ Dalian China \\ yangzhilin1118@126.com
}

\author{
Honghe Liu \\ Department of Philosophy, School of Humanities and Social \\ Science \\ Dalian University of Technology \\ Dalian China
}

\begin{abstract}
Aristotle attaches importance to the cultivation of virtue. The method of Aristotle's thought of virtue education is mainly the method of biological teleology. As the efficient cause of Aristotle's political theory, virtue education plays an important role to maintain the good social order and stability. Unwritten customs shape the moral dispositions to individuals' character and behavior, and promote the moral habits. Good virtual education is the key to the realization of self-government of citizens and the development of social stability. The four-cause scheme of analysis remains a useful instrument for this new enterprise. Through this method, we can more clearly understand the theoretical system of Aristotelian virtue education, then provide a more comprehensive theoretical basis and correct direction for our current education work.
\end{abstract} laws

Keywords-virtue; moral education; efficient cause; unwritten

\section{INTRODUCTION}

With his teacher Plato, Aristotle attaches great importance to analyze the relationship between virtue education and state rule, and that virtue education plays an important role in the governance of the polis. In his works, we can find lots of discussions about virtue education, and his thought of virtue education is recognized as the source of western educational thought.

Aristotle suggests that the Greek is the society with a common ethos. The society has a complete education system in which personal potential is activated fully, and the country is a huge educational institution which is highly concentrated in all the social impact for the human education including religious, democratic politics, public opinion, and all kinds of education and "training", that an individual must receive these education and training in order to obtain and protect his social status in an organized society.

In Aristotle's view, the education should be some social practice, which can make the society unite in a common ethos, not just for the compulsory education of minors. The essence of education is to make the political society into a harmonious whole, the means of education is shared by all the people to adjust and build its own social system, at the same time the way of education is to actively participate in public affairs and shape the personal qualities and talents by citizens in the community.

On Aristotle, each kind of scientific cognition is based on a kind of education, which makes it possible for people to achieve the accuracy within the range provided by the characteristics of the subjects. Aristotle regards education as a kind of ability to judge new things, and well-educated people have critical awareness of methodology. The most important thing of civic education is the cultivation of virtue. Human is a political animal, as Aristotle says, moral behavior is reflected in the members of the community, and the good moral action should be tested and be recognized in the common life. Virtue education is based on "the good for man" in the social community, and it has played an important role in the stable development of society and the self-realization of members in the community.

\section{THE ANALYSIS OF ARISTOTLE'S FOUR-CAUSE SCHEME}

\section{A. The final cause of the polis}

Aristotle starts his Ethics with the statement that "the good is that at which all things aim." Different from Plato, he rejects the idea of an absolute good existing separately in another world, he separates his Ethics from his Metaphysics by emphasizing that it is "the good for man", and not the transcendent good of the unmoved mover, because "if the goodness predicated of various things in common actually is a unity or something existing separately and absolute, it clearly will not be practicable or attainable by man." He emphasizes that "the Good which we are now seeking is a good within human reach," or "we instinctively feel that the Good must be something proper to a man and not easily taken from him."[1]Therefore "the good for man" is represented as "all social groups are in the Good for the purpose" in the Politics.

"The good for man" is the ultimate purpose for Aristotle political theory, from the view of the polis, the goal of virtue education is to enable citizens to have external conditions to achieve a happy life. And for individuals, the individual happiness for life is to have a rational life with virtue, so how to achieve this, a sense of perfect moral rational activity is the aim of virtue education. The concept of Aristotelian virtue education is actually a kind of rational education thought based on Metaphysics.

Aristotle suggests the human good lies in the line of the golden mean, the line to everyone to achieve the golden mean. In the Nicomachean Ethics, he insists that the golden mean is the only way to attain the highest Good, and the principle is the most correct choice; in the Politics, he also admits that the best state of life is in the golden mean, and the realization of justice 
in the community is to achieve the good for man, the mean doctrine is the highest moral standards of the community to the majority.

\section{B. The formal cause and material cause of the polis}

The Good in Ethics is the virtue of a man, and in Politics is the virtue of a community. Aristotle uses a method of analysis of four-cause scheme to expound his theory of Polis. The final cause of the best polis Aristotle emphasizes to be the realization of the good human life and the good social life is the life of noble action guided by rational principle. And the formal causes which are the social and political organization of the best polis, should be a democracy that all citizens share equally in the government, and "all have the leisure necessary for participation in civic affairs, the noble actions through which human excellence is developed and made manifest."[2]The material causes, also one of the standards of the ideal state is the "responsible and well-educated citizen". In a polis, the "responsible and well-educated citizen" will be the one that plays his proper role in which he is a member, thus contributing to its maintenance.

\section{The efficient cause of the polis}

How is the endowment of our polis with excellent matter, both natural and human, and with excellent form, to be turned to account? How is this static potential to be converted into an actuality of virtuous activity, into "a perfected activity functioning without interference from outside?" And what is the efficient cause of the good polis? Aristotle says that answer is a process of education, especially the virtual education. Only the right kind of virtue education can guarantee that the good matter and good form will not be wasted but rightly used.

The character of the citizens determines the character of the constitution of the city in the broadest sense, and virtue education is the key to shape well characteristics of citizens. The perfect society contains within itself all the means for producing men who lead lives of noble action guided by the principle of the mean. If the polis is sufficient for the good life, it will make its members good.

In most things one should guide the appetites, or passions, which activate us, by the principle of the Mean, which is as good a rule as there is available in the world of "variable things" and contingencies, which is the world of moral choice. And how are men brought to the performance of the noble actions from which good habits will arise? Aristotle suggests that it is the job of the laws and of the statesman to implant these habits in men, because "the statesman should receive his own education in these things from a study of the politicoethical experience embodied in the laws and customs of mankind". [2]

\section{THE REALIZATION OF ARISTOTELIAN VIRTUE EDUCATION}

\section{A. The training of unwritten customs}

What are the great virtues of a country? Aristotle intends to employ a standard of excellence not "above the reach of ordinary men, or a standard of education requiring exceptional endowments or equipment, or the standard of a constitution which attains an ideal height." The standard is that "the sort of life which most men are able to share and the sort of constitution which it is possible for most states to enjoy." [3]

Realizing human good and justice is the political goals of the community, and laws are a particularly useful means of promoting the Aristotelian moral virtues.

To obtain the right training for virtue from youth up is difficult unless one has been brought up under the right laws. To live a life of self-control and tenacity is not pleasant for most people, especially for the young. Therefore, their upbringing and pursuits must be regulated by laws; for once they have become familiar, they will no longer be painful... Since they must carry on these pursuits and cultivate them by habit when they are grown up, we probably need laws for this, too, and for the whole of life in general. (NE 1179b31-1180a4)

Aristotle emphasizes that all morality, not only the morality of the civics, but also the human morality- all the benefits of civilization -comes into being as a gift of the law. The natural law includes written law promulgated by the state and the unwritten rules as well, which has a "natural justice force" reflected in the writing with the formation of human society and the norms, but also reflected in the conventional norms. Aristotle points out that the practical significance of the law should be to promote the people of the whole country to enter the system of the Justice and the Good. On the other hand, only those who have the virtue of justice may know how to use the law.

The role played by laws in the development of the moral virtues is important. Aristotle repeatedly describes unwritten customs as laws and with regard to the important laws governing moral education, that "whether the laws are written or unwritten would seem to make no difference".[1] However, he notices that the supreme character of unwritten laws refer to their greater impact on individual character and behavior. Bernard Yack argues that "law's capacity to shape moral dispositions through the inculcation of certain habits is one of its greatest contributions to political life. Unwritten laws perform this function better than written laws do, since the habits they shape are more spontaneous and less alien to the individual. They are then 'more supreme' in the way that they shape moral character, and they deal with 'more supreme' matters in that they are concerned primarily with the most important political goal: moral education".[4]

\section{B. The moral disposition in habituation}

Virtue, then is a state that decides, consisting in a mean, the mean relative to us, which is defined by reference to reason, that is to say, to the reason by reference to which the prudent person would define it. There are three aspects of virtue, that is, rationality, traditional customs and emotion. In fact, with the expression of ideals and feelings, virtue turns the traditional habits which are also the idea of traditional values into their own intrinsic character. Virtue of thought arises the growth mostly from teaching that is why it needs experience and time, and virtue of character results from habit[ethos]. Therefore, for Aristotle virtue education not only refers to 
teaching which is just one aspect of virtue education, more importantly, virtue education is the broad concept including the habituation inside, if we understand the truth the meaning of Aristotelian virtue education, we will find that in fact the virtue is not innate, it needs to be formed through education and talents, and that is the basis of Aristotelian virtue education thought.

Moral virtue is a result of habit. Aristotelian moral training consists primarily in habituation: the repeated performance of particular actions until one develops a disposition toward actions of that sort.[1] Because laws demand the repeated performance of a particular sort of action in a variety of circumstances, "they are a particularly effective means of developing moral dispositions".[4]Individuals tend to internalize laws after they become familiar, turning them into the habits that anchor moral dispositions. Laws may originally command actions that cause individual pain, but "once they become familiar they are no longer painful". [1]Decrees do not set down general patterns of behavior to cover future circumstances, but with repeated performance, laws become part of our individual character, and part of the way we view the world, rather than something we told to do. Therefore, Aristotle prefers the rule of law to promote moral habits.

Aristotle insists that virtue education should be trained in childhood, his scheme of formal education begins at seven, and lasts to age of twenty-one. The basic subjects are reading, writing, physical training, and music. In particular, "music" is the important thing, for it is "music" which liberates the mind and soul and builds the good way of life. Aristotle insists that the importance of music education is almost beyond all other forms of education, because it directly adopts the mode of spiritual dialogue. The language of music is the rhythm and the mode, the object of the application is the sense of audience's hearing and mind, and its function lies in virtue. In reality, all the emotions-anger, happiness, courage and temperance-can be integrated into the music, and be performed heartily to arouse the resonance of the mind. "It serves to amuse us, to inculcate virtuous habit, and also contributes to the "cultivation of our minds and to the growth of moral wisdom', that is the development of the practical reason.'[2]

\section{The Value of Aristotelian Virtue Education}

Classical Republicans believe that "virtue triumphs over fate" and put the cultivation of virtue into a very important position. Through virtue education, we can cultivate civic responsibility and his patriotism.

"The function of man is an activity of soul which follows or implies a rational principle."[1]Aristotle distinguished two kinds of reason-contemplative reason and practical reason. The object of practical reason is the good for man, and the end of the practical reason is moral action, it works out broad criteria of moral choice and also guides the particular choices of the moral agent. Practical wisdom is "a true and reasoned state of capacity to act with regard to the things that are good or bad for man."[1]Moral virtue involves our whole composite nature, it is the excellence of that which is specially human in us, also it requires society for its development. "Education is not the storage of specific knowledge, but the universal view, even in the face of a completely strange situation, people can also be judged by the general view of the right. "[5]

The way of life of citizens determines the way of life of a community, their values, habits, virtues, vices will be the way of life of the city. If it is a good and proper way of life, the telos of the city will be realized, if not, the city will be a poor thing. As an important part of society, the cultivation of good citizens needs sufficient virtue education. "With the help of a well-formed disposition to act aright, good habit, it is a life which moves prudently from problem to problem through the maze of moral choice. It is a life, for most men, of selfgovernment rather than other-government. "[2]Decrees cannot solve all social problems, we need to cultivate the autonomy of citizens by virtue education, consciously participate in political life, and do moral constraints on their behavior, while taking participation in social life actively with the relations of others.

That man is by nature a political animal, and the efficient cause of that man being a political animal is only the teaching and habituation, then he will become a social animal which is the necessary process of human development, and the most important point in the process is that the virtue education in which family and the political system are two important organizations. Virtue education is not a passive process but an active one. In Aristotle's view, virtue education filled with a positive spirit, that education is acquired through training with people by natural, and people is improved inherent selfactualization through guidance, and not from the outside indoctrination. So people should have a positive view on virtue education and training.

Aristotle attached importance to the cultivation of virtue education, which requires cooperation between family, school and society. Virtue education makes people aware of the moral source to virtue and realizes that the moral activities is the inherent requirement of individual communication, rather than in some altruistic motives. Moral education only relying on written law will make the lack of individual responsibility and justice, then becomes fragile and tenuous. The original intention of virtue education should insist on the unity of humanity, virtue and naturality. Only in this way virtue education is moral education with human nature, then we can clear the real purpose of virtue education and training, that is to cultivate the virtue of man and the good citizen.

\section{CONCLUSION}

Aristotelian virtue education can be said to be a kind of liberal education. Education should be free and without a pattern, and should not be used in a common mode of education for individuals with different personalities, Carnes Lord says that "if culture serves a purpose at all, that purpose is essentially private - the amusement of an imaginatively privileged few or of a public in search of entertainment."[6]

First, this liberal education is a leisure education, virtue education should be based on the full development of the human rationality as the premise, and such education needs to achieve some certain conditions, that is having leisure. The 
meaning of leisure is to understand nature, understand life, and engaged in the affairs of nature.

Secondly, liberal education is also an ordinary education, which is based on the freedom of science, including gymnastics, music, painting, reading and so on, while trying to avoid mechanized and professional training.

Finally, liberal education is a product of natural education, virtue is not by nature, but it also cannot do without the human's nature, that is to say, because of the natural basis of mankind- rationality and the sociality of characteristics-people will study to develop the moral disposition and virtue. Moral disposition can be seen as internal need of virtue rather than external rules, and virtue should be consistent with biological natural, that it is not external from natural.

Furthermore, the development of educational tasks should be based on different physical and mental development stage, then make the use of different educational methods. Some scholars put forward that the Aristotelian virtue education is a great educational concept which makes a life-long benefit, and the object of virtue education not only refers to children and adolescents, also to all the citizens in the country which includes partisans with different political views as well. The purpose of virtue education is to cultivate virtue, not only to cultivate virtuous citizens.

\section{REFERENCES}

[1] Aristotle, Nicomachean Ethics[M], Liao Shenbai(ed.),Beijing: The Commercial Press, 2008, 1095b-1098a7-8, 1180b1, 1103a15-25, $1179 \mathrm{~b} 20-35$.

[2] Isaac Kramnick(ed.), Essays In the History of Political Thought[M], Prentice-Hall, Inc., Englewood Cliffs, N.J.,1969, pp.64-66, pp.80-81.

[3] Aristotle, Politics[M], Wu Shoupeng(ed.),Beijing: The Commercial Press, 2010, 1295a25-31.

[4] Bernard Yack, The Problems of a Political Animal: Community, Justice, and Conflict in Aristotelian Political Thought[M], University of California Press, 1993, pp. 181, pp. 204.

[5] Otfried Höffe, Practical Philosophy: the Model of Aristotle[M], Shen Guoqin, Li Jiedan(ed.),. Zhejiang University Press, 2011, pp. 79.(in Chinese)

[6] Carnes Lord, Education and Culture in the Political thought of Aristotle, Cornell University press, Ithaca and London, 1982, pp. 18. 